\title{
Transition Periods in the Udmurt Folk Calendar and Their Spirits
}

\section{Galina Glukhova}

e-mail: galant@udm.ru

\begin{abstract}
The article investigates the perceptions of time based on lunar and solar cycles, seasonal changes in nature, and the rhythm of agricultural work. The key events of the annual cycle in the Udmurt calendar are winter (vozhodyr/uyvozho) and summer (invozhodyr) solstices. The winter solstice period (vozhodyr, lit: transition time, crossroads / crossroads of time, the time of vozho, the time of evil spirits) and the time of the summer solstice are described. The winter period is dedicated to the winter Christmas period from January $7^{\text {th }}$ to January $19^{\text {th }}$, and includes the following components: gatherings with songs and games, divination, dressing up, and mumming. The article characterises the most important events, such as mumming and masking, as well as beliefs, rituals and prohibitions connected with the spirits of the transition time. The summer solstice is connected with the image of the Mother/ Foremother Invozho (In(')vozho-mumy), that descends from heaven to earth at that time of year. During summer solstice period the Udmurt particularly venerated heavenly powers and held calendar festivals (Gershyd, Gerber, Gyron-Bydton) in order to glorify blooming nature and peasant farmer's labour.
\end{abstract}

Keywords: masking, masks, rituals, spirits of transition times, summer solstice period, time, winter solstice period 


\section{Galina Glukhova}

Time is one of the basic features of any culture, not only in the performance of its pragmatic utilitarian functions, but also because of its symbolic functions, associated with descriptions of the world and worldview. In archaic cultures, time played a significant role in the life of the people. Unlike modern man, ancient man had a different perspective on the flow of time, as evidenced by the structure of mythological temporal representations and their different perceptions of time. Ancient man almost lived in two dimensions simultaneously, the normal chronological time and an eternally repeating sacred time.

The Udmurt folk calendar is no exception. It incorporated everything it was supposed to: perceptions of time based on lunar and solar cycles, seasonal changes in nature, the rhythm of agricultural work. The Udmurts perceived time in seasons: winter ( $t o l)$, spring (tulys), summer (guzhem), autumn (siz'yl). These seasons comprised a segment of a cycle, the year (ar), which was divided into two halfyear periods (palar), autumn-winter and spring-summer, whose boundaries were the days of the winter and summer solstices, or the beginning and the end of agricultural activities.

Various multi-genre folklore and ethnographic materials on the Udmurt traditional calendar contain information about mythological spirits of the transition periods in the year (Invozho-mumy, the spirit of the summer solstice; vozho, the spirit of winter solstice; shaytan, the spirits of Maundy (Great) Thursday; chokmor, the spirit of autumn) and in the day (dzh'ardon, sunrise; uyshor, midnight; akshan, dusk).

This article contains an analysis of vozho and Invozho-mumy, spirits of the transitional period, which is included both in rare sources from the $19^{\text {th }}$ century and the works of modern researchers on Udmurt calendar rituals (Vereshchagin 1995; Pervukhin 1884; Vladykin 1994; Pletneva 1999; Glukhova 2002, 2009; Vladykina, Glukhova 2001, etc). 
The key events of the annual cycle of the Udmurt calendar are the winter (vozhodyr/uyvozho) and summer (invozhodyr) solstices. Since the introduction of the Christian calendar and the switch to an official calendar, the winter solstice period (vozhodyr, lit: transition time; crossroads / crossroads of time; the time of vozho (mischief), the time of evil spirits) has been dedicated to the winter Christmas period from January $7^{\text {th }}$ to January $19^{\text {th }}$, and includes gatherings with songs and games, divination, dressing up, and mumming.

According to $19^{\text {th }}$ century researchers, the Udmurt had rituals of welcoming vozho as well as seeing them off. The northern Udmurt called the first day of Christmas "vozho treat" (vozhoshyd, lit: 'soup in honour of vozho'). The main event of this day was a joint meal for all of the village community (shyd-s'iyon) with the presence of the head priest (zök pop). Praying to foremother vozho (Vozhomumy), he asked her to not hurt the people during the two terrifying transitional weeks of this period and to leave when it was time; finally the priest asked vozho to grant the people a great harvest of cereals (Pervukhin 1888: 34, Essay 3).

The night before Epiphany young people chased away the spirits of the transitional period (vozho-kel'an) from this world. After New Year young villagers began to look for a house to rent for a small sum of money. They cooked food and prepared beverages in advance. The night before the celebration they went from house to house, inviting guests with the following phrase: "Come to the celebration of vozho", lit: "Come to drink the beverage of vozho" ("Vozho-braga yuyny lyktele"). The celebration lasted late into the night. Afterwards the young people of the village had gatherings in the steam bath house, where participants used a stick touched with fire to draw a circle around themselves and "listened to their fortune", i.e. took part in fortune telling. They then chased away the spirits/master of water (vozho/vumurt). Choosing a sweetheart was an indispensable element of this day. 
Early in the morning girls heated the bath houses; under the guidance of the pagan priest, men armed with axes, sticks and clubs went to the river, shouting and banging on the ice to chase vozho away. Then they washed themselves in the bath houses and went to church, where the ritual of water sanctifying was performed. On returning home, they cooked a meal of cereals with poultry (goose or duck), then the pagan priest's assistants (pokchi pop) went door to door offering prayers (Pervukhin 1888: 105-106; Vladykina, Glukhova 2011: 36-37).

Up to the mid-1950 the northern Udmurt had a tradition of meeting vozho. On the night of January $6^{\text {th }}$ young people went to crossroads "to listen to vozho go" ("vozho kylskyny"): a circle was drawn at the crossroads either with an oven fork or a frying pan holder (taba pud) as it was believed that in a circle drawn with a stick it was impossible to hear vozho: ("prostoy bodyyen nenomyre no ug kylis'ky"). There was a custom of listening at a river. The following story was recorded during an expedition to Northern Udmurt: "The night from January, $6^{\text {th }}$ to January, $7^{\text {th }}$, a few young men and girls took a fur-coat and a frying-pan holder and went to the river to listen to vozho. Having drawn a circle on the ice, they were sitting quietly. Suddenly the ice cracked and a big dog came out from beneath it. Everyone was frightened, but then they calmed down and said a prayer - and the dog disappeared" (Glukhova 1997: 83).

During this period, young people, especially girls, were very interested in divination (tunatskon). Everyone wanted to know their fate and to 'see' their soulmate. The entire Christmas period was considered favourable for divination, but the night of January $13^{\text {th }}$ was the most popular: "vozholen l'ek dyryz" (lit: the most evil/powerful time of vozho's (influence)). The elderly also looked into the future that night, to find out what the coming year would be like, whether the harvest would be good or livestock would breed. 
According to the archaic Udmurt beliefs, during the transition time, the spirits of the transition (vozho) 'leave' the waters they inhabit and come to our land. The Udmurt believed that the personification of vozho was a multitude of small creatures, white and black, zoo- and anthropomorphic. Vozho are often invisible; they only appear in certain situations looking like small, shaggy, black creatures. They are perceived mainly in the plural. They live in steam bath houses and abandoned houses, under the floor. They act like demons (shaytan). All paranormal phenomena occurring to people at night during the transition period are attributed to their tricks. Because of this, the people created a carefully thought-out system of charms and restrictions. At dusk, and at night, especially around midnight, people tried to avoid being outside, walking across a bridge or being close to abandoned houses and bathhouses, as it was believed that these places were inhabited by vozho. As a charm, they only had to call out to God: "Oste, Inmare?" ("Oh, Lord! Oh, God!”) or use profane language. Kids were prohibited from being outside at night: "En pota ber uin: vozhoos vetlo/kutozy" ("Don't walk around at night, vozho are out there / will catch you”). Crying children were also threatened with vozho: "En börd, vozhoos s'örazy nuozy" ("Don't cry or vozho will drag you (underwater) with them").

During the winter holidays, vozho are personified by mummers, who combine in their appearance both supernatural creatures and the dead ancestors. In this way, they are very similar to the shulikuns of the Vyatka and Siberian Russians. Unlike other supernatural creatures of the transition, shulikuns, like vozho, come out of the water and disappear back there.

Researchers of the $19^{\text {th }}$ century believed that vozho were in the service of witches and wizards. If the latter decide to destroy someone, they soak a shred of their clothing in water and the vozho put a curse on the owner of these things. If an ear of corn, piece of bread or wool is thrown into the water, then cattle will die and the crops won't be harvested. Sometimes vozho come out of their 
watery dwellings to fly across the sky, looking like fiery arrows. Several villages located on the banks of the same river had their own, individual, vozho. Offerings were brought to them on behalf of newlyweds; otherwise vozho would curse them with illness.

In terms of appearance, the description of these mythical creatures is rather vague. They are very small, about 14 inches or less, of different colours (mainly white, but often black) and have little horns and tails. Sometimes they may come looking like a dog, but more often they take an anthropomorphic appearance.

Vozho came in contact with people when certain taboos were violated. Their job then was to take the person with them and turn him or her into a creature like themselves. The plots of the stories are structured around vozho meeting travellers in a field or by a river after midnight. Only a particular spell (vozhokyl) can set them free. In fairy tales, the hero usually frees him- or herself from vozho by using a safe space (stove) or by using his/her skill in playing musical instruments, allowing vozho to do what they love (gambol and dance) before the first roosters crow. The hero can also restore his or her appearance with a cross. In socially-oriented fairy tales, vozho appear as either benevolent or malevolent spirits, depending on the actions of the main characters. For example, in the tale about a stepmother who hated her stepdaughter and sent her to an abandoned house after midnight to die, vozho give the stepdaughter a beautiful necklace (kamal'i), and when the stepmother sends her favourite daughter there, because of her greed, they kill her.

During the Christmas period, certain activities were prohibited, such as cleaning the floor, washing clothes, going to the bath house, removing ash from the stove, processing flax, and making malt. Washing clothes was prohibited, but if it could not be avoided, different rules applied, such as not leaving the washed clothing outside overnight otherwise vozho "will make mischief" by cutting, staining or scattering it. The water left after the washing was 
poured away only in the evening, and the spot then covered with snow. During this period, handicraft was not only permitted but also encouraged, even though it still had time limits. Spinning and knitting were allowed only during the day and late evening, at dusk (akshan).

The period of the winter solstice is contrasted and simultaneously reflected in the summer solstice, in(')vozhodyr (lit: heavenly transition, heavenly (summer/green) festivity), a time associated with ideas of the dominance of higher or heavenly forces as represented by the image of the Mother / Foremother-Invozho (In(')vozho-mumy). This deity is one of the heavenly foremothers who, during the summer/ solstice period, descends from the 'heavenly world' to earth and lives on wild clove flowers (invozhos'as'ka, gudyri-s'as'ka), hence picking them is forbidden (otherwise "lightning will strike you"). It is believed that at this time, prayer (vös') 'leaves' the sanctuary (vös' kualas' kyre pote) and so the Udmurt pray outdoors surrounded by nature during this period. The veneration of the heavenly forces during the summer/green festivity was preserved in a number of beliefs, for example at noon it was forbidden to work in the field, to swim, to make noise, to shout close to water or to wash clothes at the springs. Otherwise, the wrath of gods would fall on the people: In(')vozho-mumy would send terrible thunderstorms with hail and destroy crops. These beliefs explain the origin of the Udmurt names for the month of June: month of invozho (invozho tolez), terrible month (l'ek tolez). During this period, the Udmurt celebrate holidays dedicated to blooming nature and the labour of the peasant farmer, who grows crops (Gershyd, Gerber, Gyron-Bydton). During this time, a special sacred chant was performed (in(')vu; invu-utchan gur), which was a version of the ceremonial visit chant (vös'gur). During the ritual tour of the village, the prayer melody was played on a stringed musical instrument (krez) and sung in each of the houses visited. 
The beliefs about vozho's connection with water have also manifested themselves in the observance of certain customs during the summer festivity, for example no one performs the khorovod, round dance at the river, no one washes clothing next to water bodies, no one goes swimming at noon, and no one leads their cattle into the river to drink. People also never yell loudly at the river, make noise, or sing songs when crossing the river. Thus, modern Udmurt traditions have preserved mythological beliefs of the past, both about the mythological creatures of the transition time and about the period itself.

\section{References}

Gavrilov, B. 1880. Proizvedeniya narodnoy slovesnosti, obryady i pover'ya votyakov Kazanskoy $i$ Vyatskoy guberniy [Pieces of Folklore, Rites and Beliefs of the Votyak of Kazan and Vyatka Governorates]. Kazan: Pravoslavnoye missionerskoye obshchestvo.

Gavrilov, B. 1891. Pover'ya, obryady i obychai votyakov Mamadyshskogo uyezda, Urias'-Uchinskogo prikhoda [Beliefs, Rites and Traditions of the Votyak of Mamadysh District, Urias'-Ucha Parish]. Trudy chetvertogo arkheologicheskogo s"yezda $v$ Rossii [Works of the $4^{\text {th }}$ Congress of Archaeologists of Russia]. Kazan, pp. 80-156.

Glukhova, G. 1997. Traditsionnaya svyatochnaya obryadnost' severnykh udmurtov [Traditional Christmas Rituals of the Northern Udmurt]. In: Istoriya i kul'tura finno-ugorskikh narodov: Materialy mezhdunarodnoy studencheskoy nauchno-prakticheskoy konferencii. 1. Arheologiya. Etnologiya. Istoriya. Kraevedenie [History and Culture of the FinnoUgric Peoples: Materials of Students' International Conference. Part 1. Archeology. Ethnology. History. Regional Studies]. Glazov, pp. 82-85.

Glukhova, G. 2009. Terminologiya udmurtskogo ryazhen'ya [Terminology of Udmurt Mumming]. Traditsionnaya kul'tura v izmenyayushchemsya mire: Materialy VIII Mezhdunar. shkoly molodogo fol'klorista "Traditsionnaya kul'tura $v$ izmenyayushchemsya mire" $i$ seminara "Permistika: yazyk i stil'fol'klora" [Traditional Culture in the Changing 
World: Proc. $8^{\text {th }}$ Int. School of Young Folklorist, Traditional Culture in the Changing world, and Seminar Permistika: The Language and Style of Folklore]. Izhevsk: Udmurtskiy institut istorii, yazyka i literatury Uralskogo otdeleniya Rossiyskoy akademii nauk, pp. 45-48.

Pervukhin, N. 1888. Eskizy predaniy i byta inorodtsev Glazovskogo uyezda [Essays about the Legends and the Everyday Life of Non-Russians of the Glazov District]. Eskiz 3: Sledy yazycheskoy drevnosti v obraztsakh proizvedeniy ustnoy narodnoy poezii votyakov (liricheskikh i didakticheskikh) [Essay 3: Traces of Pagan Antiquity in Images of the (Lyrical and Didactical) Oral Folk Poetry of the Votyak]. Vyatka: Gubernskaya tipografiya.

Vereshchagin, G. 1995. Sobraniye sochineniy: $V 6 t$. [Collected Works in 6 Vols]. Vol. 1: Votyaki Sosnovskogo kraya [The Votyak of the Sosnovka Region]. Izhevsk: Udmurtskiy institut istorii, yazyka i literatury Uralskogo otdeleniya Rossiyskoy akademii nauk.

Vereshchagin, G. 1996. Sobraniye sochineniy: $V 6 t$. [Collected Works in 6 Vols]. Vol. 2: Votyaki Sarapul'skogo uyezda Vyatskoy gubernii [The Votyaks of Sarapul District of Vyatka Province]. Izhevsk: Udmurtskiy institut istorii, yazyka i literatury Uralskogo otdeleniya Rossiyskoy akademii nauk.

Vladykin, V. 1994. Religiozno-mifologicheskaya kartina mira udmurtov [The Udmurt Religious and Mythological Worldview]. Izhevsk: Udmurtia.

Vladykina, T., Glukhova G. 2011. Ar-god-bergan: Obryady i prazdniki udmurtskogo kalendarya [Year Circulation: Rituals and Celebrations of the Udmurt Calendar]. Izhevsk: Udmurtskiy universitet.

Vladykina T., Glukhova G. 2011a. Dni nedeli v sisteme predstavleniy udmurtov o vremeni [The Days of the Week within the Conception of Time in the Udmurt's Worldview]. Ezhegodnik finno-ugorskikh issledovaniy [Yearbook of Finno-Ugric Studies] 3. Izhevsk, pp. 38-54.

Vladykina T., Glukhova G. 2011b. Invu-mumy - povelitel'nitsa nebesnoy vlagi $\mathrm{v}$ traditsionnoy sisteme mirovideniya udmurtov [Invu-Mother the Goddess of Celestial Moisture in the Udmurt's Traditional Worldview]. Vestnik Udmurtskogo universiteta. Istoriya i filologiya [Bulletin of Udmurt University. History and Philology] 4. Izhevsk: Udmurtskiy institut istorii, yazyka i literatury Uralskogo otdeleniya Rossiyskoy akademii nauk, pp. 114-119. 


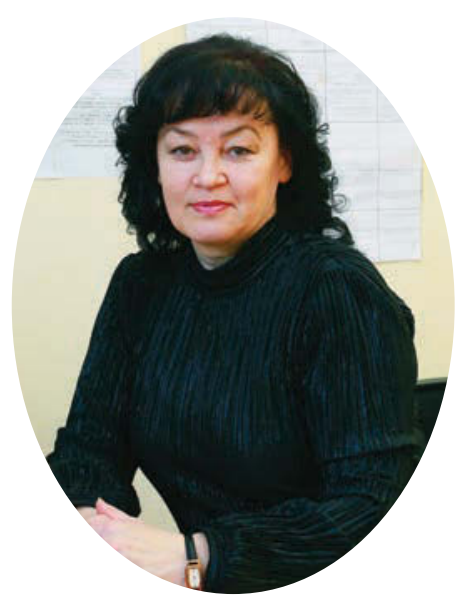

Galina Glukhova ( $\mathrm{PhD})$ is an associate professor and director of the Institute of Udmurt Philology, Finno-Ugric Studies and Journalism of Udmurt State University and teaches Udmurt literature and folklore. Her main field of interest is related to research on Udmurt and FinnoUgric folklore, Udmurt traditional culture, and the interaction of Udmurt folklore and literature.

e-mail: galant@udm.ru 